\title{
The Influencing Factors of Thai White Rice Export to International Trade (2015-2020)
}

\author{
Sadanun Sukpanich*, Wang Weiqiang ** \\ ${ }^{*}$ School of Business, Zhengzhou University \\ ** School of Business, Zhengzhou University \\ DOI: 10.29322/IJSRP.11.12.2021.p12038 \\ http://dx.doi.org/10.29322/IJSRP.11.12.2021.p12038
}

\begin{abstract}
This research aimed to study the relationship between the internal factors and the external factors that affect Thai white rice export volume in the international market. The secondary data used in this research based on trade statistical data and also the specific statistical data related to Thai white rice with both internal and external factors in 2015-2020 by monthly data. The statistical method applied in this research is Regression Analysis and Correlation. The results showed that both the internal factors include production volume and export rice (F.O.B) and the external factors include export value of export's competitor, the global rice import and consumer behavior of Thai white rice in the world market which have various influences on Thai white rice export value. This research is expected to help the Thai government about export Thai white rice to international market, trader or policy makers to make appropriate decisions, and can have a good influence on Thai international trade.
\end{abstract}

Index Terms- Export, Thai white rice, Internal and External factors, Rice Import and Export, Multiple Linear Regression

\section{INTRODUCTION}

Asia is the world's major rice-growing region. Production accounts for about $90 \%$ of the world's production, but many countries focus mainly on production for domestic consumption. Currently, the main exporting countries are Thailand, India, and Vietnam. Thailand has a rice field area of about 60 million rai. Approximately 30-32 million tons per year, or about 20 million tons, Thai rice is considered the world's top rice production base for domestic consumption. and exported to foreign countries [1], making white rice the best rice It has been very popular in many countries, and in 2017, Thai white rice also received a second award after Thai jasmine rice. The second of the world's best rice from The World Rice Conference.

Asia is the key resource of rice production in the world because Asian livelihood is highly dependent on rice for food and economics. Over 90 percent of rice production in the world is produced and consumed in the Asia-Pacific region [1]. Most of the rice production is mainly for domestic consumption. The major rice exporter is Thailand, India, and Vietnam. Currently, Thailand has 78.99 million rai of rice plantation area nationwide, which yields annual paddy output of 30 - 32 million tons or equivalent to 20 million tons of rice [2]. Thailand is the world's top rice production base and is exported to other countries worldwide [1]. Thai Hom Mali rice or Jasmin rice became the world-renowned rice. In 2017, Hom Mali rice picked up the world's best rice 2017 winner at the eight World Rice Conferences [3].

In 2021, China has the power of purchasing power to buy Thai rice. China has agreed to buy 20,000 tons of white rice from Thailand through a government-to-government $(\mathrm{G} 2 \mathrm{G})$ deal, scheduled for delivery between June and July this year. According to Keerati Rushchano, director-general of the Foreign Trade Department, the purchase came after his department negotiated with China National Cereals, Oils and Foodstuffs Corporation (Cofco), a state enterprise that supervises the mainland's annual rice import quotas. Cofco agreed to buy 20,000 tons of 5\% white rice for US $\$ 10.4$ million [4]. The negotiations are part of a joint rice marketing plan between the Commerce Ministry and Thai Rice Exporters Association to drive the country's overall rice exports to 6 million tons this year. The purchase deal is also part of a memorandum of understanding signed in early 2015 by Cofco and Thai officials to buy 2 million tons of rice, an offshoot of an investment package between the two countries that includes a high-speed rail project. Of the total purchase, 1 million tons were to be newly harvested grains and the balance older ones. However, in late 2015 Cofco agreed to sign a purchase deal to buy only 1 million tons of newly harvested grains, 700,000 tons of which have been delivered. According to Mr. Keerati, the latest deal to buy 20,000 tons of white rice has a flexible condition that allows China to import any type of rice from Thailand, with no limit in terms of quantity. He said the department is trying its best to convince Cofco to sign a purchase deal for the remaining 280,000 tons under the 1-million-tonne purchase contract [4]. The department wants to complete delivery of the remainder from the 1-million-tonne contract within this year, said Mr. Keerati. Last year, China imported 381,363 tons of Thai rice, a decrease of 19\%, with an export value of $\$ 277$ million, a decline of $10 \%$ [4]. Thai Hom mali rice comprised 137,623 tons of the total, with white rice totaling 85,663 tons, broken rice 103,549 tonnes with the remainder being sticky rice. The rice exports were handled largely by the private sector. Rice shipments to China under the $\mathrm{G} 2 \mathrm{G}$ deal were halted for a couple of years, as China delayed its purchases, citing relatively high prices for Thai rice. The Thai government set a target for rice exports of 6 million tons this year, slightly above the 5.72 million tons shipped last year. The export target of 6 million tons is expected to include 2 million tons of white rice, 1.5 million tons of Thai Hom mali, and 
1.5 million tons of parboiled rice. The remainder is made up of Pathum Thani fragrant rice, provincial fragrant rice, and sticky rice. Thailand exported a total of 7.58 million tons of rice in 2019. Export value tallied $\$ 3.72$ billion in 2020, down from $\$ 4.27$ billion in 2019 [4].

From the export data of Thai white rice, Therefore, it is an interesting point to study the factors affecting the export volume of rice to maintain the Thai white rice export market as well as to find a solution to the problem. Problems and plans to export Thai white rice exports to international markets.

\subsection{Overview Thailand Export}

According to the rice trade situation in Thailand from 2015 to 2020 showed in (Table 1) it is found that Thailand export rice value in 2015 is 9,795,781 tons and increase to 9,831,580 tons in 2016 and increased continually in 2017-2020 (11,674,331, 11,232,176, $7,583,662,5,724,681$ tons, respectively) [5].

Table 1. Total of Thai rice export quantity, 2015-2020

\begin{tabular}{|c|c|c|c|c|c|}
\hline \multicolumn{7}{|c|}{ Thai Rice Export Quantity,2015-2020,tons } \\
\hline $\mathbf{2 0 1 5}$ & $\mathbf{2 0 1 6}$ & $\mathbf{2 0 1 7}$ & $\mathbf{2 0 1 8}$ & $\mathbf{2 0 1 9}$ & $\mathbf{2 0 2 0}$ \\
\hline $9,795,781$ & $9,831,580$ & $11,674,331$ & $11,232,176$ & $7,583,662$ & $5,724,681$ \\
\hline
\end{tabular}

Source: Information and Communication Technology Center, Office of the Permanent Secretary Ministry of Commerce, Thailand.

According to the rice trade situation in Thailand from 2015 to 2020 showed in (Table 2) it is found that Thai White Rice export value in 2015 is 4,867,645 tons and increase to 4,665,090 tons in 2016 and increased continually in 2017-2020 (4,830,234, 5,715,862, 3,314,230, 2,243,162 tons, respectively) [5]. Although Thai rice export value has been increasing, Thailand still is a second of rice production volume in the world [6].

Table 2. Total of Thai White rice export quantity, 2015-2020

\begin{tabular}{|c|c|c|c|c|c|}
\hline \multicolumn{7}{|c|}{ Thai Rice Export Quantity,2015-2020,tons } \\
\hline $\mathbf{2 0 1 5}$ & $\mathbf{2 0 1 6}$ & $\mathbf{2 0 1 7}$ & $\mathbf{2 0 1 8}$ & $\mathbf{2 0 1 9}$ & $\mathbf{2 0 2 0}$ \\
\hline $4,867,645$ & $4,665,090$ & $4,830,234$ & $5,715,862$ & $3,314,230$ & $2,243,162$ \\
\hline
\end{tabular}

Source: Information and Communication Technology Center, Office of the Permanent Secretary Ministry of Commerce, Thailand.

Thai white rice is important to people around the world because of the necessary products. Especially Chinese people who like to eat Thai white rice. The value of Thai white rice exports to China has grown steadily. As a result, China has become the most important export market of Thai white rice in Thailand, in 2020 (Table 3), it was found that exports to China were the number 1, valued at 4,800.54 million baht, followed by to be the United States 3,455.39 million baht, Japan 3,218.48 million, Mozambique 2,768.49 million baht and Cameroon 2,366.18 million baht. From (Table 3) in 2020, the researcher sees that it is expedient to study the various factors affecting Thai white rice exports to key trading partners including China, the United States, Japan, and Mozambique. Therefore, this study is to serve as a guideline for improving Thai white rice for export and a guideline for developing Thailand's commercial potential in the future. 
Table 3. Thai white rice export markets to major countries (Top 15 countries; 2015-2020)

\begin{tabular}{|c|c|c|c|c|c|c|c|c|c|c|c|}
\hline \multicolumn{12}{|c|}{ Value: Million Baht } \\
\hline Countries & 2015 & Countries & 2016 & Countries & 2017 & Countries & 2018 & Countries & 2019 & Countries & 2020 \\
\hline - China & $7,585.15$ & - China & $6,162.88$ & - China & $6,019.54$ & - Philippines & $13,195.72$ & - China & $4,935.17$ & - China & $4,800.54$ \\
\hline - Philippines & $10,032.03$ & - Malaysia & $4,926.35$ & - Benin & $5,636.46$ & - Indonesia & $10,016.18$ & - Philippines & $3,931.72$ & - USA & $3,455.39$ \\
\hline - Malaysia & $4,858.47$ & - Angola & $4,305.12$ & - Mozambique & $5,421.10$ & - Angola & $5,881.46$ & - Mozambique & $3,463.94$ & - Japan & $3,218.48$ \\
\hline - Cameroon & $4,402.53$ & - Benin & $4,137.41$ & - Cameroon & $5,195.26$ & - Malaysia & $5,766.90$ & - Benin & $3,436.47$ & - Mozambique & $2,768.49$ \\
\hline - Angola & $4,166.88$ & - Indonesia & $4,100.28$ & - Angola & $5,118.77$ & - China & $5,408.17$ & - Malaysia & $3,393.74$ & - Cameroon & $2,366.18$ \\
\hline - Mozambique & $3,719.81$ & - Japan & $4,075.70$ & - Japan & $4,138.27$ & - Benin & $4,974.74$ & - Cameroon & $3,276.02$ & - Benin & $1,497.93$ \\
\hline - Japan & $3,573.30$ & - Mozambique & $4,044.15$ & - Philippines & $3,486.11$ & - Mozambique & $4,403.30$ & - Japan & $3,073.68$ & - Angola & $1,340.86$ \\
\hline - Benin & $3,448.64$ & - Cameroon & $3,833.97$ & - Malaysia & $3,305.70$ & - Kenya & $2,812.85$ & - USA & $2,520.63$ & - Congo & $1,238.79$ \\
\hline - Cote d'Ivoire & $3,377.11$ & - Philippines & $3,738.32$ & - Kenya & $2,217.58$ & - Japan & $2,674.65$ & - Kenya & $2,117.84$ & - Philippines & $1,133.70$ \\
\hline - Indonesia & $2,278.14$ & - Cote d'Ivoire & $3,499.95$ & - Iraq & $1,880.76$ & - Cameroon & $2,572.77$ & - China & $1,888.39$ & - Singapore & $1,084.58$ \\
\hline - Laos & $2,255.53$ & - Laos & $2,506.03$ & - Congo & $1,820.65$ & - Ghana & $1,815.36$ & - Congo & $1,411.14$ & - Ghana & $1,055.37$ \\
\hline - Togo & $1,886.23$ & - Congo & $1,987.85$ & - Cote d'Ivoire & $1,387.67$ & - Togo & $1,587.54$ & - Iraq & $1,059.55$ & - Australia & $1,054.19$ \\
\hline - Congo & $1,344.16$ & - Guinea & $1,002.04$ & - Iraq & $1,311.52$ & - USA & $1,354.36$ & - Hongkong & 887.52 & - Malaysia & $1,024.98$ \\
\hline - Iraq & $1,286.35$ & - Papua New Guinea & 968.27 & - Ghana & $1,001.31$ & - Congo & $1,235.10$ & - Congo & 880.75 & - Hongkong & 941.07 \\
\hline - Papua New Guinea & 612.17 & - Kenya & 869.43 & - Togo & 988.84 & - Papua New Guinea & 990.63 & - Israel & 791.29 & - Gabon & 902.00 \\
\hline Total 15 cpuntries & $8,197.32$ & & $\mathbf{5 0 , 1 5 7 . 7 5}$ & & $48,929.54$ & & $64,689.74$ & & $37,067.86$ & & $27,882.53$ \\
\hline Other & $7,926.27$ & & $9,210.44$ & & $12,962.54$ & & $13,700.24$ & & $9,272.07$ & & $9,238.97$ \\
\hline Overall & $16,123.59$ & & $59,368.18$ & & $61,892.08$ & & $78,389.98$ & & $46,339.94$ & & $37,121.50$ \\
\hline
\end{tabular}

Source: Information and Communication Technology Center Office of the Permanent Secretary, Ministry of Commerce

Thailand is mired in triple trouble gravely affecting its rice exports: decreased production because of droughts, exports at 23-year lows due to the high baht, and higher shipping charges. Amid emerging expectations that rice exports from Thailand, once the world's biggest exporter, will further drop this year, the government is stepping up efforts to regain that position by lowering export surcharges and improving rice breeds [7]. At a cabinet meeting in April, the government affirmed a plan to lower surcharges it collects from exporters for rice exports to the European Union and Britain from 2,500 baht (\$80.51) per ton to 1,200 to 1,500 baht. The government decided to prop up rice exports after they shrank $25 \%$ in 2020 from the previous year to 5.7 million tons, according to the U.S. Department of Agriculture [7]. The volume of exports was the lowest since 1997 when Thai society was thrown into confusion because of the Asian financial crisis. Thailand thus fell to being the third-largest rice exporter in 2020, surpassed by Vietnam, which exported 6.16 million tons. Weakened price competitiveness is one reason for the fall in Thailand's position as a rice exporter. Exports of Thai rice were priced at $\$ 542$ per ton in February, losing to those of Indian and Vietnamese rice, which were quoted at $\$ 393$ and $\$ 520$, respectively. Rice production in Thailand contracted because of droughts hitting its rice-producing region in 2019 and 2020 . The appreciation of the baht and steep rises in freight charges for container vessels dealt additional blows to rice exports. The baht has stayed high in value as a "safe currency" amid the COVID-19 pandemic, weakening the price competitiveness of Thai rice [7]. In addition, the global shortage of container ships has boosted transportation costs for exports. Tough conditions are expected to continue for rice exports from Thailand. Chookiat Ophaswongse, honorary president of the Thai Rice Exporters Association (TREA), told a local newspaper that exports in 2021 are forecast to decrease from the previous year to 4.5 million to 5.0 million tons. Thailand used to be the world's biggest rice exporter but fell behind India and Vietnam allegedly [7]. The quality of Thai rice dropped because farmers indulged in the government's generous protection policy. As emerging neighboring countries began to produce high-quality rice, Thailand lagged in the competition to improve breeds and lost its export competitiveness, falling from its position as the world's biggest rice exporter in 2012. The government is accelerating its comeback efforts. To promote the development of high-quality breeds, the Ministry of Agriculture and Cooperatives and the TREA are planning a contest on new rice breeds for export. The Ministry of Commerce has set a target of increasing rice exports in 2021 by $5 \%$ from the previous year to 6 million tons to pave the way for Thailand to regain its position as the top exporter by recovering the costs of the failed policy [7]. But competition with rival countries is expected to get tougher [7]. 
Graph 1. Top three rice-exporting countries (In millions of tons)

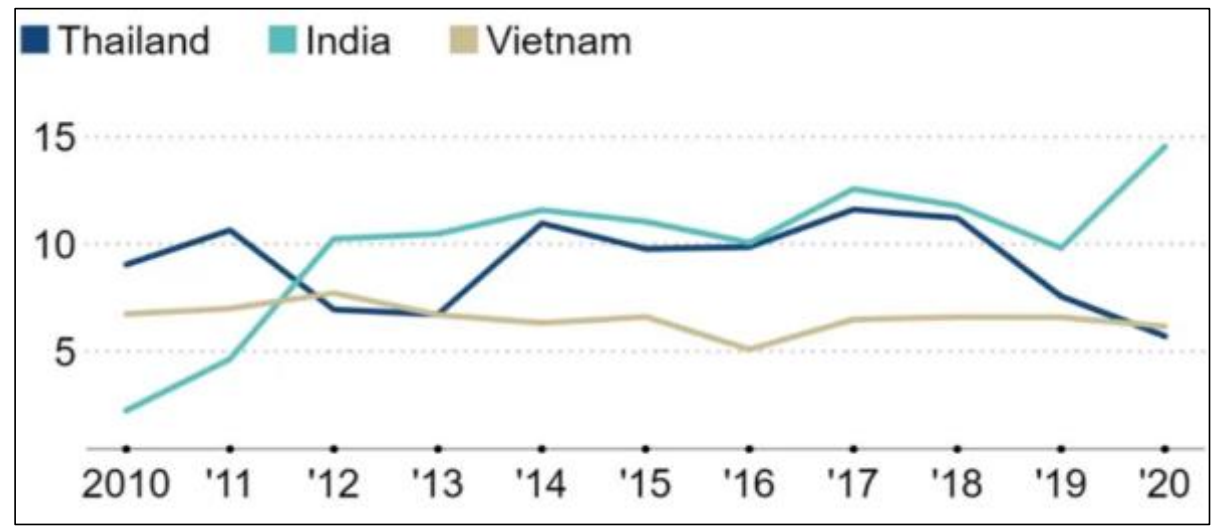

Source: U.S. Department of Agriculture

\subsection{Research Conceptual Framework}

Independent variable

\section{Internal factors}

1.Production Volume

2.Export price (F.O.B)

External factors

1.Exchange rate (US dollar:

Baht)

2.Export value of export's

competitor

3. World rice import

4.Consumer behavior
Dependent variable

Thai White rice export value to the international market (ton)Thai White rice export value,2015-2020

\section{LITERATURE REVIEW}

The researcher studies elements of the marketing environment the marketing environment consists of two important elements: The external marketing environment consists of factors that the entity or business cannot control or maybe call external or uncontrollable factors. Uncontrollable or Internal Factors and internal marketing environment It consists of factors in the organization that can be adjusted. Or it may also be called an intrinsic factor. or controllable factors controllable or internal factors external factors or uncontrollable factors It is a factor that the entity cannot control or change to meet the needs of the entity [8]. Businesses need to study various factors [8]. These are used as the basis for planning decisions. or conduct marketing activities to be in line with the changes of these factors. In this work, external factors are 1 . foreign exchange rates; 2 . quantity of rice exports of competitors; 3 . quantity of jasmine rice imports of the world market. 4. The popularity of jasmine rice consumption by people around the world. As for internal factors or controllable factors, Internal or Controllable Factors mean marketing factors that entrepreneurs can control or change to meet the needs of the business. or business because it is a factor that the business or business allocated to use in various business operations, in which the internal variables are 1. The quantity of jasmine rice production in Thailand 2. Export price (FOB) jasmine rice [8].

The researcher studies the factors affecting exports, namely the country to export various goods and services [9]. More or less depends on some important factors such as domestic production volume, cost of production, inflation rate, foreign trade policy, and foreign exchange rates It explains the foreign exchange rate that the price of goods and services sold abroad is also related to the foreign exchange rate. If the exchange rate between the country's currency and the currency of the trading partner is inappropriate It may cause the price of goods and services in foreign currencies to be cheap or too expensive. This will affect exports as well. make the country export more or a hindrance to exports [9]. 
The researcher study of factors affecting the price of jasmine rice in Thailand. The objective was to test the relationship between the price of jasmine rice [10]. with the gross domestic product, The number of rice exports, the Dong currency exchange rate against the US dollar the exchange rate of the baht against the US dollar, consumer price index [10]. Bank of Thailand interest rates, money market interest rates, the money supply in the economy, and rice yield the data used in this study It's quarterly data. From the first quarter of 2006 to the second quarter of 2016, a multiple regression analysis was performed. to study the relationship between the dependent variable and the independent variable Significant level 0.05 The results of the study found that independent variables such as consumer price index The quantity of rice exports and the quantity of rice yields There is a relationship in the same direction as the price of jasmine rice in Thailand [10]. and independent variables, which are Gross Domestic Product Dong to US Dollar Exchange Rate Thai Baht to US Dollar Exchange Rate Bank of Thailand interest rates, money market interest rates, and money supply in the economy. The relationship with the price of jasmine rice was in the opposite direction. From the literature review, the summary of variables consistent with this research was exchange rate variables, rice yield variables. and rice export volume Exchange rate variables for rice yields and rice export volume Exchange rate variables for rice yields and rice export volume [10].

\section{METHODOLOGY AND DATA}

\subsection{Collecting the Data.}

The data used in this study include 1. Secondary data: the data based on rice export value and trade situation of rice in Thailand and the key competitors in the world and international market. 2. Statistical Data: trade statistics and also the specific statistical data in rice export. Both secondary and statistical data are collected from the government and private departments, International Trade Center, The United Nations Bank and Agriculture Organization (FAO), and The Association of Rice Exporters, etc.

\subsection{Statistical Analysis}

The collective data are analyzed by the SPSS program, EView, and Excel program to perform a Multiple Linear Regression analysis to find the relationship between the dependent and independent variables [11]. The dependent variable is divided into internal and external factors. Internal factors include production volume and export price (F.O.B) and external factors include exchange rate, the export value of export's competitor, world rice import, and consumer behavior. The independent variable is Thai white rice export value to the world market.

In the model summary table, the table provides $\mathrm{R}$ and $\mathrm{R}$ Square to measure the quality of the prediction of the dependent variable and the proportion of variance in the dependent variable which can be explained by independent variables.

This research is interested in the statistical significance of each of the independent variables. If $\mathrm{p}<0.05$, the study can conclude that the coefficients are statistically significantly different from zero. It means that there is a significant correlation ship between dependent and independent variables. The p-value is located in the "sig." column.

\subsection{Inferential Statistics}

Multiple Linear Regression - the statistical procedure to predict the values of a response (dependent) variable from a collection of predictors (independent) variable values - is used in this research to model the relationship between the internal and external factors and also the marketing mix factor and Thai White rice export value in 2015-2020.

\subsection{Estimation procedures}

In regression analysis will use the format of Logarithmic Form, so create a model as follows; The internal factors

$$
\ln \mathrm{EXV}=\beta 0+\beta 1 \ln \mathrm{PV}+\beta 2 \ln \mathrm{EXP}+\varepsilon_{\mathrm{t}}
$$

In regression analysis will use the format of Logarithmic Form, so create a model as follows; The external factors

$$
\ln \mathrm{EXV}=\beta 0+\beta 1 \ln \mathrm{EXR}+\beta 2 \ln \mathrm{EXC}+\beta 3 \ln \mathrm{WIM}+\beta 4 \ln \mathrm{CB}+\varepsilon_{\mathrm{t}}
$$

In regression analysis will use the format of Logarithmic Form, so create a model as follows; between the internal and the external factor

$$
\operatorname{lnEXV}=\beta 0+\beta 1 \ln \mathrm{PV}+\beta 2 \operatorname{lnEXP}+\beta 3 \operatorname{lnEXR}+\beta 4 \operatorname{lnEXC}+\beta 5 \ln \mathrm{WIM}+\beta 6 \ln \mathrm{BB}+\varepsilon_{\mathrm{t}}
$$


Require:

$\begin{array}{ll}\operatorname{lnEXV} & =\text { Export Value (Metric Ton Value : Million Baht) } \\ \mathrm{InPV} & =\text { Production Volume (kg.per rai) } \\ \operatorname{lnEXP} & =\text { Export price (F.O.B) (USD per MT milled basis) } \\ \operatorname{lnEXR} & =\text { Foreign exchange rate (Thai baht per major trading partners currency) } \\ \operatorname{lnEXC} & =\text { Export value of export's competitor (Millions metric tons) } \\ \ln W I M & =\text { World rice import (Thousand Metric Tons) } \\ \ln C B & =\text { Consumer behavior (Thousand Metric Tons) } \\ \varepsilon_{\mathrm{t}} & =\text { Errors }\end{array}$

\section{RESULTS RESEARCH FINDING AND INTERPRETATION}

\subsection{The results of the internal factors}

The result revealed that internal factors regarding production volume and export price can explain 14 percent $(\mathrm{R} 2=0.14)$ of variation in Thai white rice export value. The Standard Error of Estimate (SEE) is 218526.35. Considering (Table 4) showed that the sig of Thai white rice production volume is 0.03 (sig. $0.03<0.05$ ). It is indicated that there is a significant correlation ship between rice production volume and rice export value as per the hypothesis. Sig of export price is 0.02 (sig. $0.02<0.05$ ). It is indicated that there is a significant correlation ship between export price and rice export value as per the hypothesis. An equation for the relationship is: Thai white rice export value $=1,077,830.10+0.01$ (Thai white rice production volume) -341.18 (export price). It can conclude that both production volume and export price influence Thai white rice export value.

Table 4. The multiple linear regression analysis results between internal factor and Thai white rice export value, 2015-2020.

\begin{tabular}{|c|c|c|c|c|c|}
\hline \multirow{3}{*}{ Variable } & \multicolumn{5}{|c|}{ Thai white rice export value, 2015-2020 } \\
\hline & \multirow{2}{*}{$\begin{array}{c}\text { Standardized } \\
\text { Coefficients }\end{array}$} & \multicolumn{2}{|c|}{$\begin{array}{l}\text { Unstandardized } \\
\text { Coefficients }\end{array}$} & \multirow{2}{*}{$\mathbf{t}$} & \multirow{2}{*}{ sig. } \\
\hline & & $\beta$ & $\begin{array}{l}\text { Coefficients } \\
\text { std. Error }\end{array}$ & & \\
\hline Constant & & $1,077,830.10$ & $145,275.85$ & 7.42 & 0.00 \\
\hline Thai white rice Production Volume & 0.25 & 0.01 & 0.01 & 2.26 & $0.03^{*}$ \\
\hline Thai white rice Export price & $(0.27)$ & (341.18) & 141.69 & (2.41) & $0.02 *$ \\
\hline
\end{tabular}

$\mathrm{R}^{2}=0.14$, Adjusted $\mathrm{R}^{2}=0.12$, S.E.est $=218526.35, \mathrm{~F}=5.6763$, sig. 0.01 , Number of Obs. 72

\subsection{The results of the external factors}

An Analysis of Multiple Linear Regression between External Factors and Thai white Rice Export Value in 2015-2020. (Table 5) The result revealed that external factors regarding exchange rate, the export value of exporting competitors, and consumption behavior can explain 57 percent $(\mathrm{R} 2=0.57)$ of variation in Thai white rice export value. The Standard Error of Estimate (SEE) is 157483.25. Considering (Table 5) showed that no sig of the exchange rate is 0.11 (no sig. because $0.11>0.05$ ). It is indicated that there is a not significant correlation ship between exchange rate and rice export value as per the hypothesis. Sig of export value of exporting competitors is 0.01 (sig. $0.01<0.05$ ). It is indicated that there is a significant correlation ship between the export value of exporting competitors and rice export value as per the hypothesis. Sig of rice import value in the world market is 0.00 (sig. $0.00<0.05$ ). It is indicated that there is a significant correlation ship between rice import value in the world market and rice export value as per the hypothesis. Sig of consumption behavior is 0.00 (sig. $0.00<0.05$ ). It is indicated that there is a significant correlation ship between consumer behavior and rice export value as per the hypothesis. An equation for relationship is Thai white rice export value $=$ 10,762,468.95 - 10.04 (rice import in the world market) $+41,775.63$ (export value of exporting competitors) - 156,001.36 (consumption behavior). According to the equation can explain that the regression coefficient (B) is -156,001.36 it means that if the consumption behavior increases by 1 unit the export value will decrease 156,001.36 units. It can conclude that external factors include the export value of exporting competitors, rice import value in the world market, and consumption behavior that influences Thai white rice export value. 
Table 5. The multiple linear regression analysis results between external factor and Thai white rice export value, 2015-2020.

\begin{tabular}{|c|c|c|c|c|c|}
\hline \multirow{3}{*}{ Variable } & \multicolumn{5}{|c|}{ Thai white rice export value, 2015-2020 } \\
\hline & \multirow{2}{*}{\begin{tabular}{c|}
$\begin{array}{c}\text { Standardized } \\
\text { Coefficients }\end{array}$ \\
Beta
\end{tabular}} & \multicolumn{2}{|c|}{$\begin{array}{c}\text { Unstandardized } \\
\text { Coefficients } \\
\end{array}$} & \multirow{2}{*}{$\mathbf{t}$} & \multirow{2}{*}{ sig. } \\
\hline & & $\beta$ & $\begin{array}{l}\text { Coefficients } \\
\text { std. Error }\end{array}$ & & \\
\hline Constant & & $10,762,468.95$ & $1,757,389.62$ & 6.12 & 0.00 \\
\hline Exchange Rate & 0.19 & $19,331.87$ & $11,755.43$ & 1.64 & 0.11 \\
\hline Export value of export's competitor & $(0.42)$ & $(10.04)$ & 3.44 & -2.92 & $0.01 *$ \\
\hline World rice import & 0.53 & $41,775.63$ & $8,606.06$ & 4.85 & $0.00 *$ \\
\hline Consumer behavior & $(0.44)$ & $(156,001.36)$ & $42,915.89$ & -3.64 & $0.00 *$ \\
\hline
\end{tabular}

$\mathrm{R}^{2}=0.57$, Adjusted $\mathrm{R}^{2}=0.57$, S.E.est $=157483.25, \mathrm{~F}=21.93$, sig. 0.00 , Number of Obs. 72

\subsection{The results of internal between the internal and the external Factors}

An Analysis of Multiple Linear Regression between the internal and the external Factors and Thai white Rice Export Value in 20152020 The result revealed that internal and external factors can explain 68 percent $(\mathrm{R} 2=0.68)$ of variation in Thai white rice export value. The Standard Error of Estimate (SEE) is 137887.66. Considering (Table 6) showed that the sig of Thai white rice production volume is 0.00 (sig. $0.00<0.05$ ). It is indicated that there is a significant correlation ship between rice production volume and rice export value as per the hypothesis. Sig of export price is 0.01 (sig. $0.01<0.05$ ). It is indicated that there is a significant correlation ship between export price and rice export value as per the hypothesis. No sig of exchange rate is 0.43 (not sig. because $0.43>0.05$ ). It is indicated that there is not a significant correlation ship between exchange rate and rice export value as per the hypothesis. Sig of export value of exporting competitors is 0.01 (sig. $0.01<0.05$ ). It is indicated that there is a significant correlation ship between the export value of exporting competitors and rice export value as per the hypothesis. Sig of rice import value in the world market is 0.00 (sig. $0.00<0.05$ ). It is indicated that there is a significant correlation ship between rice import value in the world market and rice export value as per the hypothesis. Sig of consumption behavior is 0.00 (sig. $0.00<0.05$ ). It is indicated that there is a significant correlation ship between consumer behavior and rice export value as per the hypothesis. An equation for relationship is: Thai white rice export value $=$ $9,442,619.64+0.02$ (Thai white rice production volume) -597.12 (export price) -8.53 (export value of exporting competitors) + $67,949.98$ (rice import in the world market) - 149,401.02 (consumption behavior). According to the study result can conclude that there is a strong correlation ship between internal and external factors and Thai white rice export value in 2015-2020 (the data use analysis by monthly).

In conclusion of internal factors influencing Thai white rice export value to the world market, according to an analysis from (Table 4) found that independent variable of Thai white rice production volume in the multiple linear regression equation showed 0.03 of sig value and sig value of the export price is 0.02 which is lower than 0.05 . It indicated that production volume and export price influence export value. Moreover, the equation showed the regression coefficient (B) which are 0.01 and -341.18 , respectively, which means that if the production volume increases 1 unit the export value will increase 0.01 . Similarly, if the export price increases by 1 unit, the export value will decrease by 341.18 units. While the others dependent variables in external factors did not show in the equation. It means that there is no significant correlation ship.

The conclusion of external factors influencing Thai white rice export value to the world market, according to an analysis from (Table 5) found that independent variable of the exchange rate in the multiple linear regression equation showed 0.11 of not sig value, but the sig value of the export value of exporting competitors, import value in the world, and consumption behavior are $0.01,0.00$, and 0.00 , respectively, which are lower than 0.05 . It indicated that the export value of exporting competitors, import value in the world, and consumption behavior influenced export value. In addition, the equation showed the regression coefficient (B) which is -156,001.36. It means that if the consumption behavior increases by 1 unit, the export value will decrease $156,001.36$. The equation also showed the standardized regression coefficient $(\beta)$ which is 0.44 that conform to the observation result from Thai white rice exporter which expresses that most of the consumer demands to consume white rice the most. 
Table 6. The multiple linear regression analysis results between internal and external factor and Thai white rice export value, 2015-2020.

\begin{tabular}{|c|r|r|r|r|r|}
\hline \multirow{2}{*}{ Variable } & \multicolumn{5}{|c|}{ Thai white rice export value, 2015-2020 } \\
\cline { 2 - 6 } & $\begin{array}{c}\text { Standardized } \\
\text { Coefficients }\end{array}$ & \multicolumn{2}{c|}{$\begin{array}{c}\text { Unstandardized } \\
\text { Coefficients }\end{array}$} & \multirow{2}{*}{ t } & \multirow{2}{*}{ sig. } \\
\cline { 2 - 6 } & Beta & $\beta$ & \multicolumn{1}{c|}{$\begin{array}{c}\text { Coefficients } \\
\text { std. } \text { Error }\end{array}$} & & \\
\hline Constant & & $9,442,619.64$ & $1,645,073.10$ & 5.74 & 0.00 \\
\hline Thai white rice Production Volume & 0.29 & 0.02 & 0.00 & 4.02 & $0.00^{*}$ \\
\hline Thai white rice Export price & $(0.47)$ & $(597.12)$ & 233.38 & $(2.56)$ & $0.01^{*}$ \\
\hline Exchange Rate & 0.09 & $8,880.44$ & $11,143.00$ & 0.80 & 0.43 \\
\hline Export value of export's competitor & $(0.36)$ & $(8.53)$ & 3.03 & $(2.82)$ & $0.01^{*}$ \\
\hline World rice import & 0.85 & $67,949.98$ & $12,324.30$ & 5.51 & $0.00^{*}$ \\
\hline Consumer behavior & $(0.43)$ & $(149,402.02)$ & $38,831.40$ & $(3.85)$ & $0.00^{*}$ \\
\hline
\end{tabular}

$\mathrm{R}^{2}=0.68$, Adjusted $\mathrm{R}^{2}=0.65$, S.E.est $=137887.66, \mathrm{~F}=22.80$, sig. 0.00 , Number of Obs. 72

\section{CONCLUSION}

From the empirical result of this research, it can conclude that the factors affecting Thai white Rice export value are as follow; the expected result in the relationship between the export price and export value, implying that the increase in export price decreases export value which is corresponded with [12]. Thailand is facing high competition in rice export with some exporters such as China and Vietnam which have lower export prices. Since China is the largest rice-producing country; the remaining domestic consumption is export. [13] also reported that Vietnam's comparative advantage grew stronger during this period (driven by high market share and retention rates), while Thailand did not grow as fast because of the lower price of export which is corresponded with [14] who studied A Comparison of Rice Production and Trade Competitiveness between Thailand and Vietnam in the ASEAN Market. Similarly, the exchange rate implied that the exchange rate has not affected the movement of Thai White rice export value with high confidence interval statistics testing. According to the theory mentioned in the previous study by [15], demand in agricultural products export was inelastic. When the value of bath decreases (exchange rate goes up), the price went down but the export value did not go up more. This is corresponded with [16] who found that the exchange rate has a negative effect on Thai rice export value. Moreover, the result also showed that consumer behavior has a significant with export values. It implied that the increase of consumer demand increases the export value. China is the biggest rice consumer in the world and is the main import market of Thailand. Thai rice quality is very good, long-grain, very popular with the Chinese, and Thai rice has long been familiar to Iranian consumers. Although Thai rice is more expensive than Vietnamese rice, Iran still maintains a certain number of rice imports. However, the major of Thai rice consumers are with high income who prefer the high quality of rice. It means rice price is involved with consumer demand. The consumer's behavior and rice attribute for Thai white rice and reported that the main reason for buying Thai rice is the taste of Thai rice [17]. It is also found that those Thai rice buyers are having comparatively high income and education, and have a higher degree of joyful lifestyle, especially, for those younger and labor productive age group between 26 and 35 years old. Thus, the Thai rice target group would be young consumers and consumers with more income and more years of education.

Implementation: The result indicated that the export price and the value of the Baht depreciation had a strong negative relationship with Thai rice export. It means that the rice production should be a good organization of raw material and closely on exchange rate fluctuation and use it to forecast the demand when the currency changes. Furthermore, the trader should make the consumer trust in rice products to provide the experience in eating and testing Thai white rice to enhance Thai rice market share.

\section{REFERENCE}

[1] Krishnapong, S. (2017). Development of Production Model for Khoa Hom Mali Thung Kula Rong Hai Geographical Indication with Management Technology to Increase Aromatic Frangrant along Production Chain. Bangkok: Agricultural Research Development Agency.

[2] OAE (2016). Thailand Foreign Agricultural Trade Statistics. Bangkok, Thailand: Office of Agricultural Economics, Ministry of Agriculture and Cooperatives. 
[3] Bangkok Post (2017).https://www.bangkokpost.com/learning/advanced/1357353/thailands-fragrant-hom-mali-rice-voted-worlds-best.

[4] Bangkok Post (2021). https://www.bangkokpost.com/business/2139499/china-confirms-purchase-of-20-000-tonnes-of-rice.

[5] Information Technology and Communication Center Ministry of Commerce, 2020. https://tradereport.moc.go.th/TradeThai.aspx

[6] Ma, J. C. (2018). An Analysis of Competitiveness of Thai Rice Export. Bangkok: AcademicJournal of Siam University.

[7] Marimi K, Nikkei staff writer, T. (2021). Thailand strives to regain as world's biggest rice exporter. Retrieved Jun 19, 2021, from https://ricenewstoday.com/?p=124082

[8] Patthanan Taichan. (2019). Analysis of marketing environment and marketing system. Marketing Principle02,2. Retrieved July 22, 2018, from https:// sites.google.com/site/hlakkartlad02.

[9] Ratana Saikanit. (2018) . Principles of Economics: Mahaeconomics. 2nd printing, Bangkok: Chulalongkorn University Press.

[10] Pimpakarn Putthasiri. (2016). Factors Affecting the Price of Hom Mali Paddy in Thailand. Master of Business Administration Thesis. Bangkok University.

[11] Lind, D. A., Marchal, W. G., \& Wathen, S. A. (2008). Statistical Techniques in Business and Economics with Global Data Sets (13th ed., pp. 460+512+530). New York: McGraw-Hill International.

[12] Xu, L. S. (2016). Analysis of the Comparative Advantages of Thai Rice Exports and the Influencing Factors. Agricultural Economy, 5, 121-123.

[13] Sonthaya, S. (2016). Factors Affecting Export Performance of Thai Rice Exporter in the Chinese Market. Research Journal of Business Management, 10, 74-85. https://doi.org/10.3923/rjbm.2016.74.85

[14] Pisanwanich, A. (2011). A Comparison of Rice Production and Trade Competitiveness between Thailand and Vietnam in the ASEAN Market. University of the Thai Chamber of Commerce Journal, 31, No. 2.

[15] Zheng, G. F. (2017). Thailand's Rice Export Trade Status, Problems and Corresponding Strategies. Economic Forum, 2, 130-134.

[16] Sirikul, T., Chanchai, B., \& Somchai, R. (2017). The Effect of Exchange Rates on Agricultural Goods for Export: A Case of Thailand. Academic Journal of Shinawatra International University, 7, 1-11. https://doi.org/10.22610/imbr.v7i1.1133

[17] Bunyasiri, I. N., \& Sirisupluxana, P. (2017). Consumers Behavior and Rice Attributes for Thai Hommali Rice in Sichuan Province of China. The Business and Management Review, 8, 329-341. Information Technology and Communication Center Ministry of Commerce (2020). http://tradereport.moc.go.th/TradeEng.aspx

[18] Chuaykerd, T.,Yao, S. B., Khamphilavong, S., \& Tuyen,H. T. (2020). The Impact Factors of Thai Jasmine Rice Export to International Market.Open Journal of Business and Management, 8, 1113-1121.https://doi.org/10.4236/ojbm.2020.83071

[19] Kritsanapong Sripongpongpunkul. (2013). Reducing the cost of rice production. 2nd printing, Bangkok: Chulalongkorn University Press.

[20] Xu, L.S. (2015). Analysis of the Comparative Advantages of Thai Rice Exports and the Influencing Factors. Agricultural Economy, 5(11), 121-123.

[21] Boonjit, T. (2012). The Rice Situation in Thailand. Retrieved Jan 1, 1970, from www.adb.org.

[22] Muhammad, I. (2009). Competitiveness among Asian Exporters in the World Rice Market. Retrieved Dec 14, 2015, from www.pide.org.pk.

[23] Pruetthichat, P. (2016). Thai Rice Competitiveness Development in Anticipating Export Market to Chinese. The International Journal of Business \& Management, 4(5). 319-324.

[24] Zhao, D. (2010). China - ASEAN Rice Trade Competitiveness Analysis. Financial Forum, 1(8), 149-149.

[25] Li, W.J. (2011). Analysis on the Decline of Rice Exported from Rice in Thailand in Recent Years. School of International Chinese Education, Yunnan Normal University, 2(8), 73-74.

[26] Ulrike, G. (2010). Geographical indication for Jasmine rice: Applying a log it model to predict adoption behavior of Thai farm households. Quarterly Journal of International Agriculture, 51(2), 157-185.

[27] Adam, J. (2013). Price relations between export and domestic rice markets in Thailand. Agriculture and Food Policy Studies Institute, 8(42), 48-57

\section{AUTHORS}

First Author - Sadanun Sukpanich, School of Business, Zhengzhou University, janesadanunsukpanich@gmail.com

Second Author - Wang Weiqiang, School of Business, Zhengzhou University, wangwq15@ sina.com

Correspondence Author - Sadanun Sukpanich, School of Business, Zhengzhou University, +66847638022 